DOI: https://doi.org/10.15407/techned2018.04 $: \underline{074}$

\title{
THE SYSTEM OF AUTOMATED FORMATION OF ELECTRICAL MACHINES COMPUTATIONAL MODELS FOR THE FEMM SOFTWARE ENVIRONMENT
}

Journal

Publisher

ISSN

Issue

Pages
Tekhnichna elektrodynamika

Institute of Electrodynamics National Academy of Science of Ukraine 1607-7970 (print), 2218-1903 (online)

No 4, 2018 (July/August)

$74-78$

\section{Author}

\section{V.I. Milykh*}

National Technical University «Kharkiv Polytechnic Institute»,

Kyrpychova st., 2, Kharkiv, 61002, Ukraine,

e-mail:mvikemkpi@gmail.com

* ORCID ID : http://orcid.org/0000-0002-6176-3103

\section{Abstract}

The principles of automated formation of geometric and physical models of electric machines (EM) are shown for calculating their magnetic fields by the FEMM program in the algorithmic Lua language. The basis for the organization of the algorithm and script Lua, fragments of the program text files and the source data are given. The capabilities of Lua scripts are demonstrated on the example of EM of three types. The development of such scripts in combination with the FEMM program controlled by them provides an effective tool that in the calculation of electromagnetic and power parameters and EM processes in terms of speed and capabilities is intended to replace the existing analytical formula series. References 4, figures 5. 
Key words: electric machines, magnetic field, FEMM program, graphical and physical models, formation, Lua script.

Received: 05.03.2018

Accepted: 21.03.2018

Published:

\section{References}

1. Voldek A.I., Popov V.V. Electrical Machines. Machines of alternating current. SPb: Piter Publ, 2010. 356 p. (Rus.).

2. Milykh V.I., Polyakova N.V. Automated calculations of the dynamics of a turbo-generator electromagnetic processes in the software environment FEMM. Electrical Engineering \& Electromechanics .2015, No 6.

P. 16-20. DOI:

https://doi.org/10.20998/2074-272X.2015.6.04

(Rus.).

3. Milykh V.I. Numerically-field analysis of the adequacy of the design data of three-phase induction motors and the method of their refinement on this basis. Tekhnichna Elektrodynamika . 2018. No 1. P. 47-55. (Rus.) DOI:

https://doi.org/10.15407/techned2018.01.047

(Rus.).

4. Finite Element Method Magnetics: OldVersions. FEMM 4.2 11Oct2010 Self-Installing

Executable, available at: http://www.femm.info/wiki/OldVersions 
